\title{
Tumor renal derecho con trombo en cava
}

\author{
Quicios Dorado C, Allona Almagro A.
}

Servicio de Urología, Hospital Ramón y Cajal. Madrid.

Actas Urol Esp. 2007;31(1):67

$\mathrm{M}$ ujer de 46 años que presenta hematuria monosintomática sin coágulos de 1 mes de evolución y un episodio de dolor lumbar derecho tipo cólico. Se realiza Resonancia Magnética objetivando voluminosa masa renal derecha, con infiltración tumoral de la vena renal ipsilateral y trombo tumoral en vena cava inferior infra y retrohepática (Figs. 1 y 2).

Se realiza acceso a retroperitoneo mediante apertura desde asa fija hasta hiato de Winslow para permitir completa liberación ascendente del paquete intestinal. Ligadura de vena mesentérica inferior. Movilización hepática seccionando ligamentos redondo, coronario, triangulares derecho e izquierdo y falciforme, pudiendo liberar la vena cava comenzando a nivel infrarrenal y ascendiendo hasta nivel suprahepático, con control de ambas venas renales y sección del resto de ramas excepto venas suprahepáticas, que se comprueban libres de trombo tumoral y son las únicas que fijan la cava al hígado. Si se precisa se podría ampliar el hiato diafragmático de la cava si el trombo alcanzase ese nivel, para exprimirlo hasta nivel infradiafragmático. Por estar en este caso el trombo por debajo de las venas suprahepáticas, se practicó clampaje simple de vena cava y vena renal izquierda sin control-clampaje del pedículo hepático, y posterior cavotomía con extracción del trombo (requirió pequeña escisión de pared venosa) y nefrectomía radical derecha.

Correspondencia autor: Dra. C. Quicios Dorado. Servicio de Urología. Hospital Ramón y Cajal. Ctra. de Colmenar Viejo, Km 9,100. 28034 Madrid. Tel.: 913368000

E- mail autor: cquicios@yahoo.es

Información artículo: Imágenes en Urología

(Trabajo aceptado enero 2006)

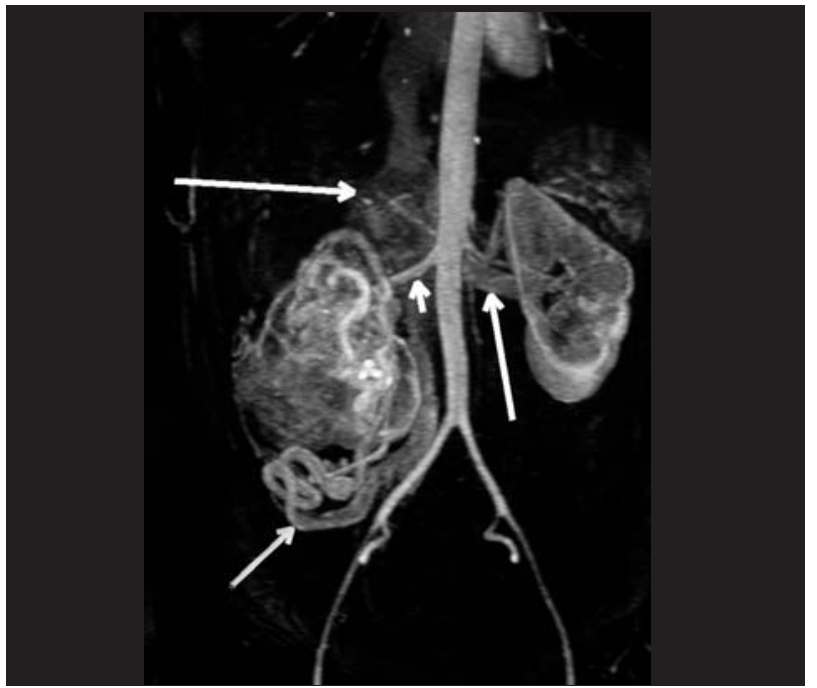

FIGURA 1. En el estudio vascular se aprecia un aporte vascular que nace de la arteria renal homóloga (flecha corta), un ovillo vascular arteriovenoso neoformativo $y$ un drenaje venoso que nace del polo inferior para unirse a la vena cava (ver flecha intermedia con cola). Se puede evidenciar un defecto de repleción tumoral que afecta a vena cava retro e infrahepática (trombo señalado con flecha larga) de 90X50X50.

Aumento de tamaño de vena renal contralateral secundario a hipertrofia compensatoria, sin infiltración tumoral.

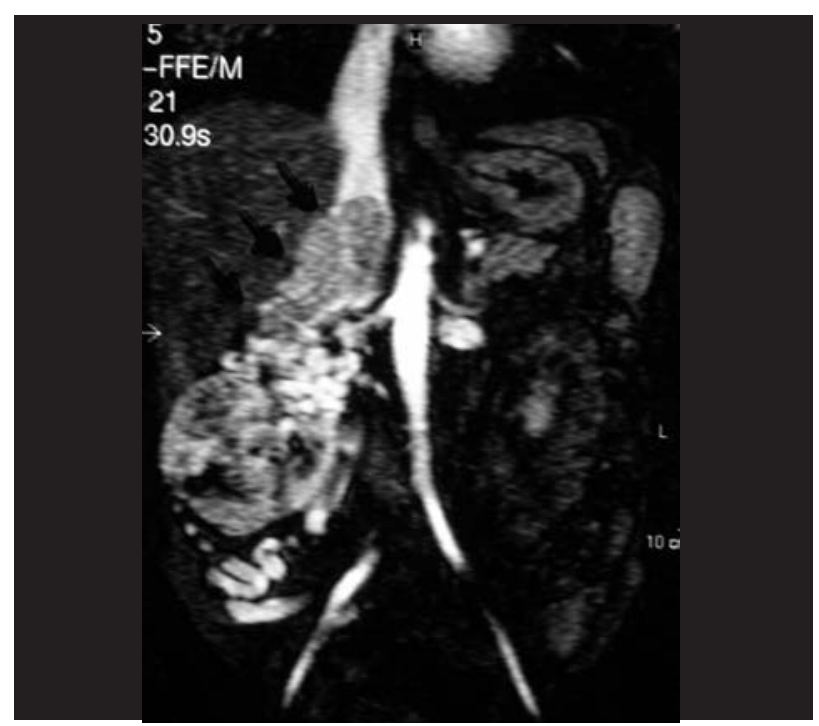

FIGURA 2 